\title{
Evaluation of Promoter Methylation of RASSF1A and $A T M$ in Peripheral Blood of Breast Cancer Patients and Healthy Control Individuals
}

\author{
Xue Cao ${ }^{1,2, *}$, Qiuqiong Tang ${ }^{1,2}$, Tim Holland-Letz ${ }^{3}$, Melanie Gündert ${ }^{1,2}{ }^{(0)}$, Katarina Cuk ${ }^{1,2}$, \\ Sarah Schott ${ }^{1}$, Jörg Heil ${ }^{4}$, Michael Golatta ${ }^{4}$, Christof Sohn ${ }^{1}$, Andreas Schneeweiss ${ }^{1,5}$ and \\ Barbara Burwinkel 1,2,* \\ 1 Molecular Biology of Breast Cancer, Department of Gynecology and Obstetrics, University of Heidelberg, \\ Heidelberg 69120, Germany; tangqiuqiong2017@foxmail.com (Q.T.); melanie.guendert@t-online.de (M.G.); \\ k.cuk@Dkfz-Heidelberg.de (K.C.); Sarah.Schott@med.uni-heidelberg.de (S.S.); \\ Christof.Sohn@med.uni-heidelberg.de (C.S.); Andreas.Schneeweiss@med.uni-heidelberg.de (A.S.) \\ 2 Division of Molecular Epidemiology (C080), German Cancer Research Center (DKFZ), Heidelberg 69120, \\ Germany \\ 3 Division of Biostatistics (C060), German Cancer Research Center (DKFZ), Heidelberg 69120, Germany; \\ t.holland-letz@Dkfz-Heidelberg.de \\ 4 Department of Gynecology and Obstetrics, University Women's Clinic, Heidelberg 69120, Germany; \\ Joerg.Heil@med.uni-heidelberg.de (J.H.); Michael.Golatta@med.uni-heidelberg.de (M.G.) \\ 5 National Centre for Tumor Diseases, Heidelberg 69120, Germany \\ * Correspondence: cxuecmu@outlook.com (X.C.); B.Burwinkel@dkfz-heidelberg.de (B.B.); \\ Tel.: +49-6221-56-8400 (X.C.); +49-6221-56-8400 (B.B.)
}

Received: 2 March 2018; Accepted: 12 March 2018; Published: 19 March 2018

\begin{abstract}
Breast cancer (BC) is the most common cancer among women and has high mortality rates. Early detection is supposed to be critical for the patient's prognosis. In recent years, several studies have investigated global DNA methylation profiles and gene-specific DNA methylation in blood-based DNA to develop putative screening markers for cancer. However, most of the studies have not yet been validated. In our study, we analyzed the promoter methylation of RASSF1A and ATM in peripheral blood DNA of 229 sporadic patients and 151 healthy controls by the MassARRAY EpiTYPER assay. There were no significant differences in DNA methylation levels of RASSF1A and $A T M$ between the sporadic $B C$ cases and the healthy controls. Furthermore, we performed the Infinium HumanMethylation450 BeadChip (450K) array analysis using 48 sporadic BC cases and 48 healthy controls (cases and controls are the same from those of the MassARRAY EpiTYPER assay) and made a comparison with the published data. No significant differences were presented in DNA methylation levels of RASSF1A and ATM between the sporadic BC cases and the healthy controls. So far, the evidence for powerful blood-based methylation markers is still limited and the identified markers need to be further validated.
\end{abstract}

Keywords: breast cancer; DNA methylation; RASSF1A; ATM

\section{Introduction}

Breast cancer (BC) is one of the most common cancers in women worldwide [1,2]. The early detection of breast cancer plays an important role in successful treatment and outcome. To date, mammography is still the main screening method for breast cancer early detection. However, the limitations of this method are noticed as tumors can only be partially identified in women (mostly young women) with dense breasts $[3,4]$. Therefore, the identification of new reliable biomarkers for the screening and diagnosis of breast cancer is urgently needed. 
Epigenetic events are critical factors in the development of human cancers [5-8]. Aberrant methylation in the promoter regions of tumor suppressor genes is related to carcinogenesis through transcriptional silencing of gene expression [9], leading to the initiation and progression of cancer [10,11]. Global hypomethylation and gene-specific hypermethylation were shown to be associated with malignancy [12-14]. Several studies showed that these epigenetic changes were early events of a variety of cancers including breast [15-17], lung [18], and colon cancer [19], and all of them could be recognized as common hallmarks in different kinds of tumors [20]. Similar alterations also existed in blood-derived DNA, suggesting that blood-based DNA methylation could reveal new biomarkers for BC screening or diagnosis [21,22]. A major advantage of blood-based DNA methylation is the easy accessibility of blood samples to investigate DNA methylation in cancer patients.

Recently, studies have been focused on two tumor suppressor genes, RAS-association domain family member 1A (RASSF1A) and ataxia-telangiectasia mutated gene (ATM). RASSF1A takes part in apoptosis induction, proliferation regulation, and microtubules stabilization [23]. Aberrant hypermethylation of RASSF1A has been demonstrated in various solid tumors, including lung, prostate, ovary, and breast cancer tissue samples [24-27]. Furthermore, a previous study has demonstrated no RASSF1A promoter hypermethylation in peripheral blood from normal blood donors, which suggested the potential of RASSF1A as a biomarker for cancers [28]. ATM plays a critical role in repairing DNA double-strand breaks and is involved in numerous processes including recognition of damaged DNA, recruitment of repair proteins, signaling to cell cycle checkpoints, transcriptional regulation, and activation of apoptosis [29]. Hypermethylation of the ATM promoter has been shown in gastric lymphoma, glioma, colonic cancer, adenoma, and breast cancer tissue samples [30-33]. Moreover, we summarized recent studies which investigated promoter methylation changes of RASSF1A and ATM in peripheral blood (plasma, serum, or whole blood) from BC patients and healthy controls (see Supplementary Table S1). To our surprise, the results of these studies were inconsistent. The promoter methylation of RASSF1A did not show a significant difference between BC patients and healthy controls in two quantitative studies [34,35]. It is worth noting that the sample sizes analyzed in these two studies were rather low. For ATM, two studies reported its hypermethylation in $\mathrm{BC}$ patients, but the $\mathrm{CpG}$ sites they investigated were located in the gene body or intragenic region instead of the promoter [36,37]. Altogether, blood-based DNA methylation of the RASSF1A and ATM promoter remains unclear in BC patients. However, these findings reveal the potential of RASSF1A and ATM promoter hypermethylation as novel biomarkers for cancer early detection.

Therefore, in this study, we aimed to conduct a case-control study with a large sample size to investigate RASSF1A and ATM promoter methylation in BC patients and healthy controls. A quantitative method, the MassARRAY EpiTYPER assay, was applied by using peripheral blood DNA in order to find useful blood-based biomarkers for BC early detection.

In addition, we compared previously published results of blood-based DNA methylation of specific genes found to be associated with breast cancer with our results by Infinium HumanMethylation450 BeadChip (450K) array analysis of sporadic breast cancer cases and healthy controls.

\section{Results}

\subsection{Promoter Methylation Levels of RASSF1A and ATM in BC Patients and Healthy Controls and Its Correlation to Clinical Characteristics}

In order to investigate the promoter methylation levels of RASSF1A and ATM, we performed the MassARRAY EpiTYPER assay by using peripheral blood DNA from BC patients and healthy controls. Our results showed that the promoter methylation levels of RASSF1A and ATM were quite low in both BC patients and healthy controls. In the amplicon of RASSF1A, 17 CpG sites were measured and the average methylation levels of all these CpG sites were 0.037 and 0.042 in the $B C$ patients and the healthy controls, respectively. Compared to the healthy controls, no significant difference was represented in the methylation levels of the BC patients among all these 17 CpG sites (see Table 1). 
Table 1. Comparison of RASSF1A DNA methylation between the BC patients and the healthy controls in peripheral blood.

\begin{tabular}{|c|c|c|c|c|c|c|}
\hline CpG Site & Case, $n$ & Control, $n$ & $\begin{array}{c}\text { BC Cases Median } \\
\text { (IQR) }\end{array}$ & $\begin{array}{c}\text { Controls Median } \\
\text { (IQR) }\end{array}$ & $p$-Value * & $p$-Value ** \\
\hline RASSF1A_CpG_1 & 222 & 144 & $0.00(0.00-0.00)$ & $0.00(0.00-0.00)$ & 0.03 & 0.31 \\
\hline RASSF1A_CpG_8 & 216 & 134 & $0.00(0.00-0.02)$ & $0.00(0.00-0.02)$ & 1.00 & 0.76 \\
\hline RASSF1A_CPG_9 & 223 & 141 & $0.01(0.00-0.02)$ & $0.01(0.00-0.03)$ & 1.00 & 0.78 \\
\hline RASSF1A_CpG_11,12 & 187 & 121 & $0.13(0.11-0.16)$ & $0.14(0.11-0.17)$ & 1.00 & 0.38 \\
\hline RASSF1A_CpG_13 & 222 & 141 & $0.04(0.00-0.08)$ & $0.04(0.00-0.08)$ & 1.00 & 0.90 \\
\hline RASSF1A_CpG_14,15 & 187 & 121 & $0.13(0.11-0.16)$ & $0.14(0.11-0.17)$ & 1.00 & 0.35 \\
\hline RASSF1A_CpG_16 & 226 & 146 & $0.02(0.00-0.03)$ & $0.02(0.02-0.03)$ & 1.00 & 0.15 \\
\hline RASSF1A_CpG_19 & 216 & 134 & $0.00(0.00-0.02)$ & $0.00(0.00-0.02)$ & 1.00 & 0.09 \\
\hline RASSF1A_CpG_20 & 216 & 134 & $0.00(0.00-0.02)$ & $0.00(0.00-0.02)$ & 1.00 & 0.34 \\
\hline RASSF1A_CpG_21,22 & 226 & 145 & $0.05(0.04-0.06)$ & $0.05(0.03-0.07)$ & 0.62 & 0.64 \\
\hline RASSF1A_CpG_23 & 226 & 146 & $0.00(0.00-0.00)$ & $0.00(0.00-0.00)$ & 0.28 & 0.70 \\
\hline RASSF1A_CpG_24 & 226 & 145 & $0.03(0.02-0.05)$ & $0.03(0.02-0.07)$ & 1.00 & 0.79 \\
\hline RASSF1A_CpG_25 & 223 & 141 & $0.01(0.00-0.02)$ & $0.01(0.00-0.03)$ & 1.00 & 0.31 \\
\hline RASSF1A_CpG_26 & 226 & 146 & $0.04(0.03-0.05)$ & $0.04(0.03-0.05)$ & 1.00 & 0.76 \\
\hline MEAN & 226 & 146 & $0.037(0.029-0.048)$ & $0.042(0.032-0.054)$ & 0.25 & 0.78 \\
\hline
\end{tabular}

Abbreviations: IQR: interquartile range. ${ }^{*} p$-value for the difference between controls and patients was analyzed by Mann-Whitney $U$ test and was adjusted by Bonferroni-Holm method, $\alpha=0.00333$. ${ }^{* *} p$-value for the difference between controls and patients was analyzed by logistic regression and was adjusted by age, $\alpha=0.05$.

As for ATM, $30 \mathrm{CpG}$ sites were analyzed in its amplicon. The average methylation levels of all investigated CpG sites of ATM were 0.047 and 0.048 in the BC patients and the healthy controls, respectively. No visible difference was detected in the methylation levels of these $\mathrm{CpG}$ sites between the BC cases and the healthy controls (see Table 2). The CpG sites of RASSF1A and ATM analyzed in this study are shown in Supplementary Figure S1.

Table 2. Comparison of ATM DNA methylation between the BC patients and the healthy controls in peripheral blood.

\begin{tabular}{|c|c|c|c|c|c|c|}
\hline CpG Site & Case, $n$ & Control, $n$ & $\begin{array}{c}\text { BC Cases Median } \\
\text { (IQR) }\end{array}$ & $\begin{array}{c}\text { Controls Median } \\
\text { (IQR) }\end{array}$ & $p$-Value * & $p$-Value $* *$ \\
\hline ATM_CpG_1 & 222 & 146 & $0.02(0.01-0.03)$ & $0.02(0.01-0.02)$ & 1.00 & 0.95 \\
\hline ATM_CpG_2,3,4,5 & 142 & 95 & $0.07(0.06-0.10)$ & $0.07(0.06-0.09)$ & 1.00 & 0.91 \\
\hline ATM_CpG_6 & 223 & 146 & $0.00(0.00-0.00)$ & $0.00(0.00-0.00)$ & 1.00 & 0.37 \\
\hline ATM_CpG_7,8 & 223 & 146 & $0.05(0.03-0.06)$ & $0.04(0.03-0.06)$ & 1.00 & 0.60 \\
\hline ATM_CpG_10,11 & 221 & 145 & $0.11(0.10-0.13)$ & $0.12(0.10-0.13)$ & 1.00 & 0.95 \\
\hline ATM_CpG_12 & 223 & 146 & $0.00(0.00-0.00)$ & $0.00(0.00-0.00)$ & 1.00 & 0.94 \\
\hline ATM_CpG_13,14 & 223 & 146 & $0.03(0.02-0.04)$ & $0.03(0.02-0.04)$ & 1.00 & 0.43 \\
\hline ATM_CpG_17 & 219 & 145 & $0.00(0.00-0.04)$ & $0.01(0.00-0.04)$ & 1.00 & 0.73 \\
\hline ATM_CpG_18,19 & 223 & 146 & $0.13(0.12-0.16)$ & $0.14(0.12-0.18)$ & 0.22 & 0.18 \\
\hline ATM_CpG_20,21 & 223 & 146 & $0.02(0.02-0.03)$ & $0.02(0.02-0.03)$ & 1.00 & 0.36 \\
\hline ATM_CpG_26 & 219 & 146 & $0.06(0.04-0.09)$ & $0.07(0.05-0.09)$ & 1.00 & 0.21 \\
\hline ATM_CpG_27 & 223 & 146 & $0.11(0.10-0.12)$ & $0.11(0.10-0.12)$ & 1.00 & 0.66 \\
\hline ATM_CpG_28 & 222 & 146 & $0.02(0.02-0.03)$ & $0.02(0.02-0.03)$ & 1.00 & 0.75 \\
\hline ATM_CpG_29 & 223 & 146 & $0.03(0.02-0.03)$ & $0.03(0.02-0.03)$ & 1.00 & 0.68 \\
\hline ATM_CpG_32 & 223 & 145 & $0.00(0.00-0.00)$ & $0.00(0.00-0.00)$ & 1.00 & 0.53 \\
\hline ATM_CpG_33 & 223 & 146 & $0.00(0.00-0.00)$ & $0.00(0.00-0.00)$ & 1.00 & 0.15 \\
\hline ATM_CpG_34 & 223 & 146 & $0.13(0.10-0.16)$ & $0.14(0.10-0.18)$ & 1.00 & 0.70 \\
\hline ATM_CpG_35 & 219 & 145 & $0.00(0.00-0.04)$ & $0.01(0.00-0.04)$ & 1.00 & 0.78 \\
\hline ATM_CpG_36 & 223 & 145 & $0.00(0.00-0.00)$ & $0.00(0.00-0.00)$ & 1.00 & 0.14 \\
\hline ATM_CpG_37 & 223 & 146 & $0.13(0.10-0.16)$ & $0.14(0.10-0.18)$ & 1.00 & 0.16 \\
\hline ATM_CpG_38 & 192 & 135 & $0.00(0.00-0.01)$ & $0.00(0.00-0.01)$ & 1.00 & 0.95 \\
\hline ATM_CpG_39 & 223 & 146 & $0.02(0.01-0.04)$ & $0.02(0.01-0.03)$ & 1.00 & 0.91 \\
\hline MEAN & 223 & 146 & $0.047(0.042-0.055)$ & $0.048(0.042-0.056)$ & 1.00 & 0.37 \\
\hline
\end{tabular}

Abbreviations: IQR: interquartile range. ${ }^{*} p$-value for the difference between controls and patients was analyzed by Mann-Whitney $U$ test and was adjusted by Bonferroni-Holm method, $\alpha=0.00227$. ${ }^{* *} p$-value for the difference between controls and patients was analyzed by logistic regression and was adjusted by age, $\alpha=0.05$.

To further explore the association between the promoter methylation of RASSF1A / ATM and the clinical characteristics of the BC patients, statistical analyses were performed. All the BC patients were classified into different subgroups according to their clinical properties (see Table 3). To our surprise, no significant correlation was represented between the methylation levels of all the CpG sites 
in RASSF1A or ATM amplicons and the clinical characteristics of the BC patients (see Supplementary Tables S2 and S3).

Table 3. Characteristics of the sporadic BC patients.

\begin{tabular}{cc}
\hline Characteristics & BC Patients Number (\%) \\
\hline Tumor, lymph node and metastasis (TNM) Stage \\
\hline stage 0 & $1(0.4 \%)$ \\
stage I & $69(30.1 \%)$ \\
stage II & $72(31.4 \%)$ \\
stage III & $15(6.6 \%)$ \\
stage IV & $4(1.7 \%)$ \\
neoadjuvant chemotherapy * & $50(21.8 \%)$ \\
unknown & $18(7.9 \%)$ \\
\hline \multicolumn{1}{c}{ Type of BC } \\
Ductal & $179(78.2 \%)$ \\
Lobular & $13(5.7 \%)$ \\
Ductal-Lobular & $3(1.3 \%)$ \\
Others & $4(1.7 \%)$ \\
unknown & $10(4.4 \%)$ \\
\hline
\end{tabular}

\begin{tabular}{cc}
\hline \multicolumn{2}{c}{ Estrogen receptor (ER) Status ${ }^{\text {a }}$} \\
\hline negative & $21(9.2 \%)$ \\
positive & $160(69.9 \%)$ \\
unknown & $48(21.0 \%)$ \\
\hline
\end{tabular}

\begin{tabular}{cc}
\hline \multicolumn{2}{c}{ Progesterone receptor (PR) Status ${ }^{\text {a }}$} \\
\hline negative & $36(15.7 \%)$ \\
positive & $145(63.3 \%)$ \\
unknown & $48(21.0 \%)$ \\
\hline
\end{tabular}

\begin{tabular}{cc}
\hline Human epidermal growth factor receptor 2 (HER2) Status ${ }^{b}$ \\
\hline negative & $165(72.1 \%)$ \\
positive & $16(7.0 \%)$ \\
unknown & $48(21.0 \%)$ \\
\hline
\end{tabular}

${ }^{a}$ Immunoreactive score (IRS): ER/PR negative: IRS 0-2; ER/PR positive: IRS 3-12. ${ }^{\mathrm{b}}$ HER2 negative: IHC-score 0-1; HER2 positive: IHC-score 3; If IHC-score = 2, FISH/CISH was further analyzed, HER2 is recognized as positive if it is amplified. * Patients were treated with neoadjuvant chemotherapy, no stage is given here.

Taken together, these results demonstrated that the promoter methylation levels of RASSF1A and $A T M$ included in our study were not statistically different between the BC patients and the healthy controls.

\subsection{Comparison of the Results from This Study with the Results of Infinium HumanMethylation450 BeadChip} Array and with Literature

To better interpret the results of the Sequenom MassARRAY EpiTYPER assay, we also performed an epigenome-wide Infinium HumanMethylation450 BeadChip array (450K array). In line with the MassARRAY data, the methylation levels of all the investigated CpG sites of RASSF1A and ATM were rather low. No significant difference was revealed in the methylation levels of RASSF1A and $A T M$ between the BC patients and the healthy controls. Interestingly, we identified four $\mathrm{CpG}$ sites of RASSF1A and 13 CpG sites of ATM which were identical in both the Sequenom MassArray EpiTYPER assay and the $450 \mathrm{~K}$ array. These data confirmed the findings of our MassARRAY analysis (see Table 4). 
Table 4. Comparison of methylation levels of peripheral blood DNA between different analytical methods.

\begin{tabular}{|c|c|c|c|c|c|c|c|c|c|c|}
\hline \multirow{2}{*}{ Gene } & \multicolumn{5}{|c|}{ 450K Results } & \multicolumn{5}{|c|}{ Sequenom MassARRAY EpiTYPER Assay } \\
\hline & CpG & $\begin{array}{c}\text { Cases No./CTL } \\
\text { No. }\end{array}$ & BC Cases Mean \pm SD & $\begin{array}{c}\text { CTL } \\
\text { Mean } \pm \text { SD }\end{array}$ & $p$-Value ${ }^{a}$ & CpG & $\begin{array}{c}\text { Cases No./CTL } \\
\text { No. }\end{array}$ & $\begin{array}{c}\text { BC Cases Median } \\
\text { (IQR) }\end{array}$ & $\begin{array}{l}\text { CTL Median } \\
\text { (IQR) }\end{array}$ & $p$-Value ${ }^{\mathrm{b}}$ \\
\hline \multirow{10}{*}{ RASSF1A } & cg 12966367 & $48 / 48$ & $0.029 \pm 0.005$ & $0.027 \pm 0.004$ & 0.19 & CpG_1 & $229 / 151$ & $0.00(0.00-0.00)$ & $0.00(0.00-0.00)$ & 0.03 \\
\hline & cg25486143 & $48 / 48$ & $0.014 \pm 0.002$ & $0.014 \pm 0.002$ & 0.80 & CpG_14 & $229 / 151$ & $0.13(0.11-0.16)$ & $0.14(0.11-0.17)$ & 1.00 \\
\hline & cg06172942 & $48 / 48$ & $0.038 \pm 0.007$ & $0.038 \pm 0.011$ & 0.91 & CpG_15 & $229 / 151$ & $0.13(0.11-0.16)$ & $0.14(0.11-0.17)$ & 1.00 \\
\hline & $\operatorname{cg} 03297783$ & $48 / 48$ & $0.015 \pm 0.002$ & $0.016 \pm 0.002$ & 0.35 & CpG_19 & $229 / 151$ & $0.00(0.00-0.02)$ & $0.00(0.00-0.02)$ & 1.00 \\
\hline & $\operatorname{cg} 08047457^{*}$ & $48 / 48$ & $0.030 \pm 0.004$ & $0.030 \pm 0.004$ & 0.87 & $\mathrm{CpG} \_2$ & $229 / 151$ & - & - & - \\
\hline & $\operatorname{cg} 25747192 *$ & $48 / 48$ & $0.043 \pm 0.007$ & $0.043 \pm 0.008$ & 0.99 & $\mathrm{CpG} 3$ & $229 / 151$ & - & - & - \\
\hline & $\operatorname{cg} 21554552 *$ & $48 / 48$ & $0.031 \pm 0.005$ & $0.030 \pm 0.005$ & 0.42 & $\mathrm{CpG}_{-} 4$ & $229 / 151$ & - & - & - \\
\hline & $\operatorname{cg} 27569446 *$ & $48 / 48$ & $0.012 \pm 0.002$ & $0.011 \pm 0.002$ & 0.65 & CpG_5 & $229 / 151$ & - & - & - \\
\hline & $\operatorname{cg} 04540383 *$ & $48 / 48$ & $0.032 \pm 0.004$ & $0.033 \pm 0.005$ & 0.92 & CpG_18 & $229 / 151$ & - & - & - \\
\hline & Mean & $48 / 48$ & $0.204 \pm 0.005$ & $0.205 \pm 0.005$ & 0.56 & Mean & $229 / 151$ & $0.037(0.029-0.048)$ & $0.042(0.032-0.054)$ & 0.25 \\
\hline \multirow{17}{*}{ ATM } & $\operatorname{cg} 19288979$ & $48 / 48$ & $0.075 \pm 0.006$ & $0.076 \pm 0.007$ & 0.95 & CpG_1 & $229 / 151$ & $0.02(0.01-0.03)$ & $0.02(0.01-0.02)$ & 1.00 \\
\hline & cg10610482 & $48 / 48$ & $0.040 \pm 0.005$ & $0.037 \pm 0.005$ & 0.31 & $\mathrm{CpG} \_2$ & 229/151 & $0.07(0.06-0.10)$ & $0.07(0.06-0.09)$ & 1.00 \\
\hline & cg12848864 & $48 / 48$ & $0.051 \pm 0.007$ & $0.048 \pm 0.007$ & 0.38 & $\mathrm{CpG}_{-} 4$ & $229 / 151$ & $0.07(0.06-0.10)$ & $0.07(0.06-0.09)$ & 1.00 \\
\hline & $\operatorname{cg} 03165700$ & $48 / 48$ & $0.047 \pm 0.007$ & $0.044 \pm 0.005$ & 0.16 & $\mathrm{CpG}-5$ & $229 / 151$ & $0.07(0.06-0.10)$ & $0.07(0.06-0.09)$ & 1.00 \\
\hline & cg15504467 & $48 / 48$ & $0.027 \pm 0.003$ & $0.026 \pm 0.004$ & 0.36 & $\mathrm{CpG}-6$ & $229 / 151$ & $0.00(0.00-0.00)$ & $0.00(0.00-0.00)$ & 1.00 \\
\hline & cg05033322 & $48 / 48$ & $0.028 \pm 0.004$ & $0.027 \pm 0.003$ & 0.82 & CpG_7 & $229 / 151$ & $0.05(0.03-0.06)$ & $0.04(0.03-0.06)$ & 1.00 \\
\hline & cg16693212 & $48 / 48$ & $0.033 \pm 0.004$ & $0.031 \pm 0.004$ & 0.29 & $\mathrm{CpG} \_8$ & $229 / 151$ & $0.05(0.03-0.06)$ & $0.04(0.03-0.06)$ & 1.00 \\
\hline & cg15370815 & $48 / 48$ & $0.074 \pm 0.007$ & $0.072 \pm 0.007$ & 0.60 & CpG_10 & $229 / 151$ & $0.11(0.10-0.13)$ & $0.12(0.10-0.13)$ & 1.00 \\
\hline & cg16788234 & $48 / 48$ & $0.052 \pm 0.008$ & $0.051 \pm 0.007$ & 0.82 & CpG_11 & $229 / 151$ & $0.11(0.10-0.13)$ & $0.12(0.10-0.13)$ & 1.00 \\
\hline & cg24030675 & $48 / 48$ & $0.013 \pm 0.001$ & $0.013 \pm 0.001$ & 0.58 & CpG_17 & $229 / 151$ & $0.00(0.00-0.04)$ & $0.01(0.00-0.04)$ & 1.00 \\
\hline & $\operatorname{cg} 06053805$ & $48 / 48$ & $0.012 \pm 0.001$ & $0.011 \pm 0.003$ & 0.14 & CpG_18 & $229 / 151$ & $0.13(0.12-0.16)$ & $0.14(0.12-0.18)$ & 0.22 \\
\hline & $\operatorname{cg} 06750635$ & $48 / 48$ & $0.012 \pm 0.001$ & $0.011 \pm 0.001$ & 0.69 & CpG_19 & $229 / 151$ & $0.13(0.12-0.16)$ & $0.14(0.12-0.18)$ & 0.22 \\
\hline & cg25400013 & $48 / 48$ & $0.016 \pm 0.002$ & $0.016 \pm 0.001$ & 0.94 & CpG_21 & $229 / 151$ & $0.02(0.02-0.03)$ & $0.02(0.02-0.03)$ & 1.00 \\
\hline & $\operatorname{cg} 20342375$ * & $48 / 48$ & $0.021 \pm 0.003$ & $0.020 \pm 0.002$ & 0.085 & CpG_9 & $229 / 151$ & - & - & - \\
\hline & $\operatorname{cg} 22837512 *$ & $48 / 48$ & $0.023 \pm 0.003$ & $0.023 \pm 0.002$ & 0.99 & CpG_15 & $229 / 151$ & - & - & - \\
\hline & $\operatorname{cg} 18391757^{*}$ & $48 / 48$ & $0.025 \pm 0.004$ & $0.025 \pm 0.004$ & 0.72 & CpG_22 & $229 / 151$ & - & - & - \\
\hline & Mean & $48 / 48$ & $0.236 \pm 0.002$ & $0.235 \pm 0.002$ & 0.79 & Mean & $229 / 151$ & $0.047(0.042-0.055)$ & $0.048(0.042-0.056)$ & 1.00 \\
\hline
\end{tabular}

${ }^{\mathrm{a}} p$-value was ajusted by age, batch, cell type and multiple test. ${ }^{\mathrm{b}} p$-value for the difference between breast cancer patients and healthy controls was analyzed by Mann-Whitney $U$ test and was adjusted by Bonferroni-Holm method, $\alpha=0.00333$ and $\alpha=0.00227$ for RASSF1A and ATM respectively. ${ }^{*}$ CpG sites were included in RASSF1A and ATM amplicons but were not investigated by Sequenom MassARRAY EpiTYPER assay in this study. Abbreviations: CTL, control; BC, breast cancer. 
To understand the current research status on gene-specific DNA methylation in blood-based DNA as a screening biomarker for breast cancer early detection, we reviewed recent studies which investigated blood-based DNA methylation of BRCA1, APC, RARB, ESR1, CDH1, SYK, TIMP3, GSTP1, $D A P K$, and IGF2 between $B C$ patients and healthy controls [38]. Interestingly, the results of blood DNA methylation levels of BRCA1, APC, RARB, ESR1, TIMP3, and GSTP1 were inconsistent among the previous studies, but a higher frequency of methylated $D A P K$ in peripheral DNA was reported in BC cases compared to healthy controls in several studies (see Supplementary Table S4) $[36,37,39,40]$. Moreover, the methylation levels of CDH1, IGF2, and $S Y K$ were not significantly different in peripheral blood DNA between BC cases and healthy controls according to the published data [34,35,41-44].

Next, we investigated the methylation levels of these genes by a $450 \mathrm{~K}$ array from our own group. Compared to the healthy controls, the methylation levels did not show a significant difference in most of the $\mathrm{CpG}$ sites of these genes in the $\mathrm{BC}$ cases, except for a few $\mathrm{CpG}$ sites including BRCA1 (cg13782816), APC (cg01240931 and cg14511739), ESR1 (cg25565730), CDH1 (cg26508465), and GSTP1 (cg06841499) (see Supplementary Table S4).

\section{Discussion}

In this work, we conducted a large cohort case-control study to investigate the promoter methylation changes of two tumor suppressor genes (RASSF1A and ATM) in peripheral blood DNA as potential epigenetic markers for breast cancer risk and early detection. To our surprise, no significant differences in the methylation level of RASSF1A and ATM in peripheral blood DNA were revealed between $\mathrm{BC}$ cases and healthy controls.

RASSF1A methylation in BC patients has been analyzed by several groups using either blood serum or blood plasma samples [39,40,45-50]. Jo-Heon Kim et al. observed significantly higher methylation frequencies of RASSF1A in ductal carcinoma in situ (DCIS) or invasive ductal carcinoma (IDC) than in control subjects, but the CpG sites they investigated in the RASSF1A promoter region were different from ours [49]. In contrast, Zmetakova et al., evaluated DNA methylation profiles of the RASSF1A promoter by pyrosequencing in invasive breast cancer. They demonstrated no significant difference in peripheral blood DNA between BC cases and healthy controls, which was in line with our findings [35]. Moreover, another study by Brooks et al., also showed no significant difference in RASSF1A promoter methylation between BC cases and controls, although they used serum instead of whole blood samples. Interestingly, the CpG sites analyzed in their study partially overlapped with some CpG sites in our RASSF1A amplicon [51].

For ATM, we demonstrated that the promoter methylation level in peripheral blood DNA of BC patients was not significantly different from that of healthy controls. Consistent with this, Flanagan et al. detected no significant difference in methylation of the ATM promoter CpG islands in white blood cell DNA between BC cases and healthy controls [36].

In fact, it is difficult to compare the results between our study and the published data, where different techniques for methylation analysis have been used and different $\mathrm{CpG}$ sites have been investigated. Moreover, depending on the technique used for quantification, methylation levels can differ, even for the same CPG site [52]. The promoter region is located at around 100-1000 base pairs before the transcription start sites. A length of around 100-500 base pairs can be amplified by PCR, which means that the investigation cannot cover the entire promoter region. Currently, there is no standard for blood DNA methylation analysis. The exact quantity of methylated CpG sites as the biomarker for breast cancer risk remains unclear.

In our study, we chose whole blood DNA to investigate the methylation levels. Recently, the pivotal significance of circulating tumor cells (CTCs) has been realized for breast cancer patients, even in patients without metastases. It is possible that the whole blood was mixed by CTCs, further affecting the analysis of RASSF1A or ATM promoter methylation. In fact, peripheral blood samples from epidemiological studies always comprise mixed cell populations, but it is not feasible or practical to fractionate cell populations in an epidemiological study setting [53]. At present, many studies use cell-free DNA 
(cfDNA) to investigate DNA methylation, but its low concentration and small fragments may disrupt the detection of blood-based DNA methylation [54-56]. Even if the pooling method can improve the concentration of cfDNA, the possible bias may still occur. In addition, the origin of cfDNA is still uncertain and it requires more evidence to elucidate the mechanism of cfDNA release [57].

Radpour et al. demonstrated that heterogeneity of methylation changes exists in carcinogenesis, but no single gene has been shown to be methylated in all types of breast cancer [58]. Therefore, a panel of genes should be considered as biomarkers for breast cancer screening. Our $450 \mathrm{~K}$ data analyzed additional ten genes to screen for potential methylation CpG sites as biomarkers for breast cancer early detection. The methylation levels did not show a significant difference in most of the CPG sites of these genes in $\mathrm{BC}$ cases.

With the analysis of RASSF1A and ATM using the MassARRAY EpiTYPER assay, we could confirm the results of our $450 \mathrm{~K}$ methylation data for these two genes. However, the methylation levels detected in our samples were quite low. We identified that the average methylation levels of RASSF1A and ATM were at around 0.04 and 0.05 , respectively. In accordance with this, a study by Cho et al., reported that the methylation level of RASSF1A was below 4\% [34]. The MassARRAY system could detect the methylation level as low as 5\% [59]. For some of the analyzed CpG sites, no detectable quantitative value could be gained because the results were below this detection limit. Future studies applying digital PCR techniques in next-generation sequencing (PCR/NGS)-based analysis may improve the detection limit.

Another limitation of the $450 \mathrm{~K}$ results was the limited sample size, which included only 48 cases and 48 controls. Thus, larger multicenter prospective study cohorts are needed to validate these results.

In conclusion, the promoter CPG methylation status of RASSF1A and ATM in peripheral blood included in our study was unable to distinguish between $B C$ cases and healthy controls. Further prospective studies should be carried out to evaluate whether RASSF1A or ATM promoter methylation could be suitable biomarkers for breast cancer early detection [39].

\section{Materials and Methods}

\subsection{Study Population}

This study was approved by the Ethics Committee of University Hospital in Heidelberg (S-039/2008, 27 April 2009; S-175/2010, 26 May 2010). All samples of the BC cases and the healthy controls were obtained from centers in southwest Germany. All the enrolled patients and the healthy controls were Caucasian and were given written informed consent. Peripheral whole-blood samples from the $\mathrm{BC}$ patients were successively collected before therapeutic treatments at the University Hospital of Heidelberg. Clinical characteristics of the BC patients were defined according to the American Joint Committee on Cancer staging manual [60]. Detailed characteristics of the sporadic BC cases were described in Table 3. In the group of healthy controls, peripheral whole-blood samples were consecutively collected from blood donors at the University Hospital of Heidelberg. Donors approved the use of their blood samples for research purposes. All the donors were healthy when donating blood and none of them had a family history of BC. Blood samples were collected between 2011 and 2014 and a total of 229 sporadic BC patients and 151 healthy controls were randomly selected for this study (see Table 5).

Table 5. Sample Information.

\begin{tabular}{ccccc}
\hline Gene & Sample Type & Group & Number & Age ( $y$, Mean \pm SD) \\
\hline \multirow{2}{*}{ RASSF1A } & \multirow{2}{*}{ Peripheral blood DNA } & Sporadic BC & 229 & $48.37 \pm 7.08$ \\
& & Controls & 151 & $43.76 \pm 14.49$ \\
\hline \multirow{2}{*}{ ATM } & \multirow{2}{*}{ Peripheral blood DNA } & Sporadic BC & 229 & $48.37 \pm 7.08$ \\
& & Controls & 151 & $43.76 \pm 14.49$ \\
\hline
\end{tabular}




\subsection{DNA Isolation and Bisulfite Conversion}

DNA was isolated from $200 \mu \mathrm{L}$ aliquots of whole blood using the QIAamp DNA Blood Mini Kit (Qiagen, Hilden, Germany) according to the manufacturer's recommendations. NanoDrop ND-1000 UV/Vis-Spectralphotometer 3.3 (peqLab, Erlangen, Germany) was used to measure DNA quality and quantity. DNA bisulfite treatment was carried out using the EZ-96 DNA methylation Gold kit (Zymo Research Corporation, Orange, CA, USA) as described by the manufacturer.

\subsection{Primer Design and PCR Amplification}

The PCR primers for RASSF1A and ATM amplicon sequences (see Tables 6 and 7) were designed with the online tool "epidesigner" (http://www.epidesigner.com/start3.html). PCR was performed in a final reaction volume of $6 \mu \mathrm{L}$ which included bisulfite-treated DNA $(10 \mathrm{ng} / \mu \mathrm{L})$, CoralLoad Buffer (10×; Qiagen, Valencia, CA, USA), forward and reverse primers ( $1 \mu \mathrm{M}$ of each; Sigma, Darmstadt, Germany), dNTPs (10 mM), and HotStar Taq DNA polymerase ( $5 \mathrm{U} / \mu \mathrm{L}$; Qiagen, Valencia, CA, USA). The touch-down PCR profile was $5 \mathrm{~min}$ of activation at $95^{\circ} \mathrm{C}, 30 \mathrm{~s}$ of denaturation at $94{ }^{\circ} \mathrm{C}$, and $30 \mathrm{~s}$ of annealing at a temperature reduced from $59^{\circ} \mathrm{C}$ to $53^{\circ} \mathrm{C}$ (every $2{ }^{\circ} \mathrm{C}$ ), followed by a final extension at $72{ }^{\circ} \mathrm{C}$ for $1 \mathrm{~min}$. After a maintenance of $5 \mathrm{~min}$ at $72{ }^{\circ} \mathrm{C}$, the reaction ended up at $4{ }^{\circ} \mathrm{C}$. PCR products were electrophoresed on $1 \%$ agarose gels and evaluated under ultraviolet light.

Table 6. Bisulfite-specific primers for the target amplicons.

\begin{tabular}{ccr}
\hline Target & Primer & Sequence $\left(\mathbf{5}^{\prime} \mathbf{- 3}^{\prime} \mathbf{)}\right.$ \\
\hline RASSF1A & $\begin{array}{c}\text { sense } \\
\text { antisense }\end{array}$ & $\begin{array}{r}\text { aggaagagagGTAATGGAAATTTGGGTGTAGGGAT } \\
\text { cagtaatacgactcactatagggagaaggctCTAACAACCCAAAATAACAAAACCA }\end{array}$ \\
\hline \multirow{2}{*}{ TTM } & $\begin{array}{c}\text { sense } \\
\text { antisense }\end{array}$ & $\begin{array}{c}\text { aggaagagagAGGGAAAATTTTTGGTTTTAAAGGT } \\
\text { cagtaatacgactcactatagggagaaggctCCATATCCACCAATAACCAAC }\end{array}$ \\
\hline
\end{tabular}

Table 7. Sequences of the target amplicons.

\begin{tabular}{|c|c|}
\hline Amplicon & Sequence $\left(5^{\prime}-3^{\prime}\right)$ \\
\hline RASSF1A & $\begin{array}{l}\text { GCAATGGAAACCTGGGTGCAGGGACTGTGGGGCCCGAAGGCGGGGCTGGGCGCG } \\
\text { CTCTCGCAGAGCCCCCCCCGCCTTGCCCTTCCTTCCCTCCTTCGTCCCCTCCTCACA } \\
\text { CCCCACCCCGGACGGCCACAACGACGGCGACCGCAAAGCACCACGCGGAGATAC } \\
\text { CCGTGTTTCTGGAGGCCAGCTTTACTGTGCTAGAGGAAGAGGGTCCCCACATCCGG } \\
\text { CCCTGGCCCTCCTGGTCCGGTTTGCTGAAGCAACACACTTGGCCTACCCACTGGGT } \\
\text { GGGGCAGGAAGTCTCGAGCCTTCACTTGGGGTGAGGAGGAGGGAGATCGGTCAG } \\
\text { CAGCTTTACCGCCCGCTCTGCTCTCCACTGCGGAGACTGGGGCTCCGGCAGAGGC } \\
\text { TGGACCGTGATCTTGAGGTTCAGGGGTGCATTCTGGGTGGATTCCCTTGGCATGGG } \\
\text { TGGTCGGCCCTCAGCAACTGCAGCCCTCATTTGGCTCTGTCACCCTGGGCTGCCAG }\end{array}$ \\
\hline$A T M$ & $\begin{array}{l}\text { AGGGAAAACCTTTGGCCTCAAAGGTCCTTCTGTCCAGCATAGCCGGGTCCAATAAC } \\
\text { CCTCCATCCCGCGTCCGCGCTTACCCAATACAAGCCGGGCTACGTCCGAGGGTAAC } \\
\text { AACATGATCAAAACCACAGCAGGAACCACAATAAGGAACAAGACTCAGGTTAAAG } \\
\text { CAAACACAGCGACAGCTCCTGCGCCGCATCTCCTGGTTCCAGTGGCGGCACTGAAC } \\
\text { TCGCGGCAATTTGTCCCGCCTCTTTCGCTTCACGGCAGCCAATCGCTTCCGCCAGAG } \\
\text { AAAGAAAGGCGCCGAAATGAAACCCGCCTCEGTTCGCCTTCGGAACTGTCGTCACT } \\
\text { TCCGTCCTCAGACTTGGAGGGGCGGGGATGAGGAGGGCGGGGAGGACGACGAGGG } \\
\underline{\text { CGAAGAGGGTGGGTGAGAGCCCCGGAGCCCGAGCCGAAGGGCGAGCCGCAAACG }} \\
\text { CTAAGTCGCTGGCCATTGGTGGACATGG }\end{array}$ \\
\hline
\end{tabular}

\subsection{Methylation Analysis}

For methylation analysis, the Sequenom MassARRAY EpiTYPER assay was applied as described previously [61]. The PCR amplicons were conducted subsequently according to the protocol of the Sequenom EpiTYPER Assay and cleaned by Resin. A nanodispenser was used to transfer the products to a 384 SpectroCHIP (SEQUENOM, San Diego, CA, USA). The chips were read by a Sequenom Mass Spectrometer system (SEQUENOM, San Diego, CA, USA). Data was gathered by SpectroACQUIRE 
v3.3.1.3 software (SEQUENOM, San Diego, CA, USA) and visualized with MassArray EpiTYPER v1.0 software (SEQUENOM, San Diego, CA, USA). Results were depicted as "beta" values ( $\beta$ ) between 0 and 1.

\subsection{K Methylation Study}

Epigenome-wide DNA methylation profiling on 96 age matched blood DNAs from 48 sporadic BC cases and 48 healthy controls was performed by applying Infinium HumanMethylation450 BeadChip $(450 \mathrm{~K})$ as described before [61]. In brief, DNA was extracted from whole blood samples. Then, the DNA samples were bisulfate converted, purified, and applied to the BeadChips (Illumina, San Diego, CA, USA). Image processing and data extraction were performed following Illumina's instructions. Further details of the $450 \mathrm{~K}$ array analysis were given in Tang et al. [61].

\subsection{Statistical Analysis}

SPSS statistics 24.0 (IBM, NY, USA) was used for statistical analyses of the data. Normality of distribution was evaluated by the Kolmogorov-Smirnoff test. Non-normally distributed data was analyzed by the nonparametric Mann-Whitney $U$ or Kruskal-Wallis $H$ test. All tests were performed two-tailed at the significance level $p<0.05$.

Supplementary Materials: Supplementary materials can be found at http:/ /www.mdpi.com/1422-0067/19/3/900/s1.

Acknowledgments: We thank Sabine Serick and Yanxiang Jiang for their technical support. This study was supported by the German Cancer Research Center (DKFZ) and University Women's Clinic, Heidelberg. Xue Cao was financed by the China Scholarship Council (CSC).

Author Contributions: Xue Cao, Qiuqiong Tang, and Barbara Burwinkel conceived and designed the experiments; Xue Cao, Qiuqiong Tang, and Katarina Cuk performed the experiments; Xue Cao and Tim Holland-Letz analyzed the data; Sarah Schott, Jörg Heil, Michael Golatta, Christof Sohn, and Andreas Schneeweiss contributed materials; Xue Cao, Michael Golatta, and Barbara Burwinkel wrote the paper.

Conflicts of Interest: The authors declare no conflict of interest. The founding sponsors had no role in the design of the study; in the collection, analyses, or interpretation of data; in the writing of the manuscript, and in the decision to publish the results.

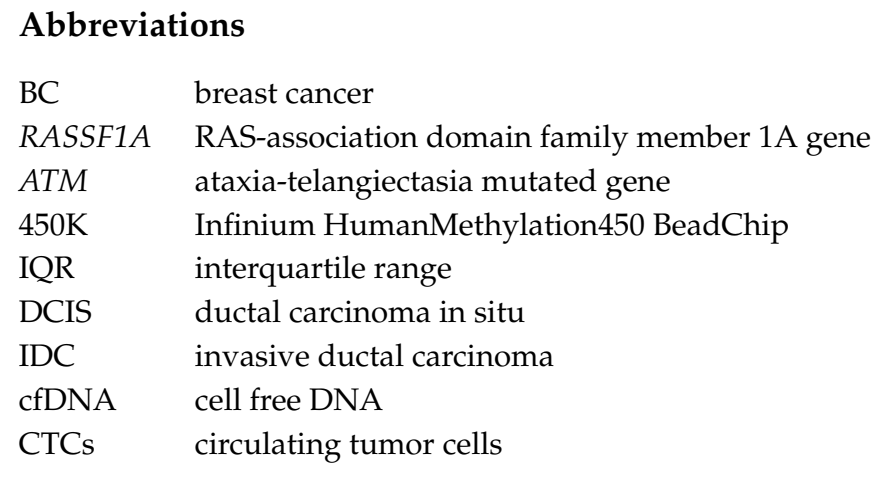

\section{References}

1. Ferlay, J.; Soerjomataram, I.; Dikshit, R.; Eser, S.; Mathers, C.; Rebelo, M.; Parkin, D.M.; Forman, D.; Bray, F. Cancer incidence and mortality worldwide: Sources, methods and major patterns in GLOBOCAN 2012. Int. J. Cancer 2015, 136, E359-E386. [CrossRef] [PubMed]

2. Siegel, R.; Naishadham, D.; Jemal, A. Cancer statistics, 2013. CA Cancer J. Clin. 2013, 63, 11-30. [CrossRef] [PubMed]

3. Elmore, J.G.; Barton, M.B.; Moceri, V.M.; Polk, S.; Arena, P.J.; Fletcher, S.W. Ten-year risk of false positive screening mammograms and clinical breast examinations. N. Engl. J. Med. 1998, 338, 1089-1096. [CrossRef] [PubMed]

4. Alagaratnam, T.T.; Wong, J. Limitations of mammography in Chinese females. Clin. Radiol. 1985, 36, $175-177$. [CrossRef] 
5. Baylin, S.B.; Herman, J.G.; Graff, J.R.; Vertino, P.M.; Issa, J.P. Alterations in DNA methylation: A fundamental aspect of neoplasia. Adv. Cancer Res. 1998, 72, 141-196. [PubMed]

6. Sadikovic, B.; Al-Romaih, K.; Squire, J.A.; Zielenska, M. Cause and consequences of genetic and epigenetic alterations in human cancer. Curr. Genom. 2008, 9, 394-408. [CrossRef] [PubMed]

7. Merlo, A.; Herman, J.G.; Mao, L.; Lee, D.J.; Gabrielson, E.; Burger, P.C.; Baylin, S.B.; Sidransky, D. 5' CpG island methylation is associated with transcriptional silencing of the tumour suppressor p16/CDKN2/MTS1 in human cancers. Nat. Med. 1995, 1, 686-692. [CrossRef] [PubMed]

8. Herman, J.G.; Umar, A.; Polyak, K.; Graff, J.R.; Ahuja, N.; Issa, J.P.; Markowitz, S.; Willson, J.K.; Hamilton, S.R.; Kinzler, K.W.; et al. Incidence and functional consequences of hMLH1 promoter hypermethylation in colorectal carcinoma. Proc. Natl. Acad. Sci. USA 1998, 95, 6870-6875. [CrossRef] [PubMed]

9. Baylin, S.B. DNA methylation and gene silencing in cancer. Nat. Clin. Pract. Oncol. 2005, 2 (Suppl. 1), S4-S11. [CrossRef] [PubMed]

10. Leonhardt, H.; Cardoso, M.C. DNA methylation, nuclear structure, gene expression and cancer. J. Cell. Biochem. 2000, 79 (Suppl. 35), 78-83. [CrossRef]

11. Yuan, Y.; Liu, H.; Sahin, A.; Dai, J.L. Reactivation of SYK expression by inhibition of DNA methylation suppresses breast cancer cell invasiveness. Int. J. Cancer 2005, 113, 654-659. [CrossRef] [PubMed]

12. Robertson, K.D.; Jones, P.A. DNA methylation: Past, present and future directions. Carcinogenesis 2000, 21, 461-467. [CrossRef] [PubMed]

13. Momparler, R.L. Cancer epigenetics. Oncogene 2003, 22, 6479-6483. [CrossRef] [PubMed]

14. Ehrlich, M. DNA hypomethylation, cancer, the immunodeficiency, centromeric region instability, facial anomalies syndrome and chromosomal rearrangements. J. Nutr. 2002, 132 (Suppl. 8), 2424S-2429S. [CrossRef] [PubMed]

15. Umbricht, C.B.; Evron, E.; Gabrielson, E.; Ferguson, A.; Marks, J.; Sukumar, S. Hypermethylation of 14-3-3 sigma (stratifin) is an early event in breast cancer. Oncogene 2001, 20, 3348-3353. [CrossRef] [PubMed]

16. Evron, E.; Dooley, W.C.; Umbricht, C.B.; Rosenthal, D.; Sacchi, N.; Gabrielson, E.; Soito, A.B.; Hung, D.T.; Ljung, B.; Davidson, N.E.; et al. Detection of breast cancer cells in ductal lavage fluid by methylation-specific PCR. Lancet 2001, 357, 1335-1336. [CrossRef]

17. Evron, E.; Umbricht, C.B.; Korz, D.; Raman, V.; Loeb, D.M.; Niranjan, B.; Buluwela, L.; Weitzman, S.A.; Marks, J.; Sukumar, S. Loss of cyclin D2 expression in the majority of breast cancers is associated with promoter hypermethylation. Cancer Res. 2001, 61, 2782-2787. [PubMed]

18. Belinsky, S.A.; Nikula, K.J.; Palmisano, W.A.; Michels, R.; Saccomanno, G.; Gabrielson, E.; Baylin, S.B.; Herman, J.G. Aberrant methylation of p16(INK4a) is an early event in lung cancer and a potential biomarker for early diagnosis. Proc. Natl. Acad. Sci. USA 1998, 95, 11891-11896. [CrossRef] [PubMed]

19. Esteller, M.; Sparks, A.; Toyota, M.; Sanchez-Cespedes, M.; Capella, G.; Peinado, M.A.; Gonzalez, S.; Tarafa, G.; Sidransky, D.; Meltzer, S.J.; et al. Analysis of adenomatous polyposis coli promoter hypermethylation in human cancer. Cancer Res. 2000, 60, 4366-4371. [PubMed]

20. Hanahan, D.; Weinberg, R.A. Hallmarks of cancer: The next generation. Cell 2011, 144, 646-674. [CrossRef] [PubMed]

21. Li, L.; Choi, J.Y.; Lee, K.M.; Sung, H.; Park, S.K.; Oze, I.; Pan, K.F.; You, W.C.; Chen, Y.X.; Fang, J.Y.; et al. DNA methylation in peripheral blood: A potential biomarker for cancer molecular epidemiology. J. Epidemiol. 2012, 22, 384-394. [CrossRef] [PubMed]

22. Jung, K.; Fleischhacker, M.; Rabien, A. Cell-free DNA in the blood as a solid tumor biomarker-A critical appraisal of the literature. Clin. Chim. Acta 2010, 411, 1611-1624. [CrossRef] [PubMed]

23. Dammann, R.; Li, C.; Yoon, J.H.; Chin, P.L.; Bates, S.; Pfeifer, G.P. Epigenetic inactivation of a RAS association domain family protein from the lung tumour suppressor locus 3p21.3. Nat. Genet. 2000, 25, 315-319. [PubMed]

24. Richter, A.M.; Walesch, S.K.; Dammann, R.H. Aberrant Promoter Methylation of the Tumour Suppressor RASSF10 and Its Growth Inhibitory Function in Breast Cancer. Cancers 2016, 8, 26. [CrossRef] [PubMed]

25. Choi, Y.L.; Kang, S.Y.; Shin, Y.K.; Choi, J.S.; Kim, S.H.; Lee, S.J.; Bae, D.S.; Ahn, G. Aberrant hypermethylation of RASSF1A promoter in ovarian borderline tumors and carcinomas. Virchows Arch. 2006, 448, 331-336. [CrossRef] [PubMed]

26. Pfeifer, G.P.; Dammann, R. Methylation of the tumor suppressor gene RASSF1A in human tumors. Biochemistry 2005, 70, 576-583. [CrossRef] [PubMed] 
27. Liu, L.; Yoon, J.H.; Dammann, R.; Pfeifer, G.P. Frequent hypermethylation of the RASSF1A gene in prostate cancer. Oncogene 2002, 21, 6835-6840. [CrossRef] [PubMed]

28. Kristensen, L.S.; Raynor, M.P.; Candiloro, I.; Dobrovic, A. Methylation profiling of normal individuals reveals mosaic promoter methylation of cancer-associated genes. Oncotarget 2012, 3, 450-461. [CrossRef] [PubMed]

29. Ahmed, M.; Rahman, N. ATM and breast cancer susceptibility. Oncogene 2006, 25, 5906-5911. [CrossRef] [PubMed]

30. Begam, N.; Jamil, K.; Raju, S.G. Promoter Hypermethylation of the ATM Gene as a Novel Biomarker for Breast Cancer. Asian Pac. J. Cancer Prev. 2017, 18, 3003-3009. [PubMed]

31. Majchrzak-Celinska, A.; Paluszczak, J.; Szalata, M.; Barciszewska, A.M.; Nowak, S.; Kleszcz, R.; Sherba, A.; Baer-Dubowska, W. The methylation of a panel of genes differentiates low-grade from high-grade gliomas. Tumour Biol. 2015, 36, 3831-3841. [CrossRef] [PubMed]

32. Huang, Q.; Su, X.; Ai, L.; Li, M.; Fan, C.Y.; Weiss, L.M. Promoter hypermethylation of multiple genes in gastric lymphoma. Leuk. Lymphoma 2007, 48, 1988-1996. [CrossRef] [PubMed]

33. Bai, A.H.; Tong, J.H.; To, K.F.; Chan, M.W.; Man, E.P.; Lo, K.W.; Lee, J.F.; Sung, J.J.; Leung, W.K. Promoter hypermethylation of tumor-related genes in the progression of colorectal neoplasia. Int. J. Cancer 2004, 112, 846-853. [CrossRef] [PubMed]

34. Cho, Y.H.; Yazici, H.; Wu, H.C.; Terry, M.B.; Gonzalez, K.; Qu, M.; Dalay, N.; Santella, R.M. Aberrant promoter hypermethylation and genomic hypomethylation in tumor, adjacent normal tissues and blood from breast cancer patients. Anticancer Res. 2010, 30, 2489-2496. [PubMed]

35. Zmetakova, I.; Danihel, L.; Smolkova, B.; Mego, M.; Kajabova, V.; Krivulcik, T.; Rusnak, I.; Rychly, B.; Danis, D.; Repiska, V.; et al. Evaluation of protein expression and DNA methylation profiles detected by pyrosequencing in invasive breast cancer. Neoplasma 2013, 60, 635-646. [CrossRef] [PubMed]

36. Flanagan, J.M.; Munoz-Alegre, M.; Henderson, S.; Tang, T.; Sun, P.; Johnson, N.; Fletcher, O.; Dos Santos Silva, I.; Peto, J.; Boshoff, C.; et al. Gene-body hypermethylation of ATM in peripheral blood DNA of bilateral breast cancer patients. Hum. Mol. Genet. 2009, 18, 1332-1342. [CrossRef] [PubMed]

37. Brennan, K.; Garcia-Closas, M.; Orr, N.; Fletcher, O.; Jones, M.; Ashworth, A.; Swerdlow, A.; Thorne, H.; Riboli, E.; Vineis, P.; et al. Intragenic ATM methylation in peripheral blood DNA as a biomarker of breast cancer risk. Cancer Res. 2012, 72, 2304-2313. [CrossRef] [PubMed]

38. Tang, Q.; Cheng, J.; Cao, X.; Surowy, H.; Burwinkel, B. Blood-based DNA methylation as biomarker for breast cancer: A systematic review. Clin. Epigenetics 2016, 8, 115. [CrossRef] [PubMed]

39. Ahmed, I.A.; Pusch, C.M.; Hamed, T.; Rashad, H.; Idris, A.; El-Fadle, A.A.; Blin, N. Epigenetic alterations by methylation of RASSF1A and DAPK1 promoter sequences in mammary carcinoma detected in extracellular tumor DNA. Cancer Genet. Cytogenet. 2010, 199, 96-100. [CrossRef] [PubMed]

40. Dulaimi, E.; Hillinck, J.; Ibanez de Caceres, I.; Al-Saleem, T.; Cairns, P. Tumor suppressor gene promoter hypermethylation in serum of breast cancer patients. Clin. Cancer Res. 2004, 10 Pt 1, 6189-6193. [CrossRef] [PubMed]

41. Cho, Y.H.; McCullough, L.E.; Gammon, M.D.; Wu, H.C.; Zhang, Y.J.; Wang, Q.; Xu, X.; Teitelbaum, S.L.; Neugut, A.I.; Chen, J.; et al. Promoter Hypermethylation in White Blood Cell DNA and Breast Cancer Risk. J. Cancer 2015, 6, 819-824. [CrossRef] [PubMed]

42. Harrison, K.; Hoad, G.; Scott, P.; Simpson, L.; Horgan, G.W.; Smyth, E.; Heys, S.D.; Haggarty, P. Breast cancer risk and imprinting methylation in blood. Clin. Epigenetics 2015, 7, 92. [CrossRef] [PubMed]

43. Ito, Y.; Koessler, T.; Ibrahim, A.E.; Rai, S.; Vowler, S.L.; Abu-Amero, S.; Silva, A.L.; Maia, A.T.; Huddleston, J.E.; Uribe-Lewis, S.; et al. Somatically acquired hypomethylation of IGF2 in breast and colorectal cancer. Hum. Mol. Genet. 2008, 17, 2633-2643. [CrossRef] [PubMed]

44. Widschwendter, M.; Apostolidou, S.; Raum, E.; Rothenbacher, D.; Fiegl, H.; Menon, U.; Stegmaier, C.; Jacobs, I.J.; Brenner, H. Epigenotyping in peripheral blood cell DNA and breast cancer risk: A proof of principle study. PLoS ONE 2008, 3, e2656. [CrossRef] [PubMed]

45. Hoque, M.O.; Feng, Q.; Toure, P.; Dem, A.; Critchlow, C.W.; Hawes, S.E.; Wood, T.; Jeronimo, C.; Rosenbaum, E.; Stern, J.; et al. Detection of aberrant methylation of four genes in plasma DNA for the detection of breast cancer. J. Clin. Oncol. 2006, 24, 4262-4269. [CrossRef] [PubMed]

46. Papadopoulou, E.; Davilas, E.; Sotiriou, V.; Georgakopoulos, E.; Georgakopoulou, S.; Koliopanos, A.; Aggelakis, F.; Dardoufas, K.; Agnanti, N.J.; Karydas, I.; et al. Cell-free DNA and RNA in plasma as a new molecular marker for prostate and breast cancer. Ann. N. Y. Acad. Sci. 2006, 1075, 235-243. [CrossRef] [PubMed] 
47. Yazici, H.; Terry, M.B.; Cho, Y.H.; Senie, R.T.; Liao, Y.; Andrulis, I.; Santella, R.M. Aberrant methylation of RASSF1A in plasma DNA before breast cancer diagnosis in the Breast Cancer Family Registry. Cancer Epidemiol. Biomarkers Prev. 2009, 18, 2723-2725. [CrossRef] [PubMed]

48. Van der Auwera, I.; Elst, H.J.; Van Laere, S.J.; Maes, H.; Huget, P.; van Dam, P.; Van Marck, E.A.; Vermeulen, P.B.; Dirix, L.Y. The presence of circulating total DNA and methylated genes is associated with circulating tumour cells in blood from breast cancer patients. Br. J. Cancer 2009, 100, 1277-1286. [CrossRef] [PubMed]

49. Kim, J.H.; Shin, M.H.; Kweon, S.S.; Park, M.H.; Yoon, J.H.; Lee, J.S.; Choi, C.; Fackler, M.J.; Sukumar, S. Evaluation of promoter hypermethylation detection in serum as a diagnostic tool for breast carcinoma in Korean women. Gynecol. Oncol. 2010, 118, 176-181. [CrossRef] [PubMed]

50. Kloten, V.; Becker, B.; Winner, K.; Schrauder, M.G.; Fasching, P.A.; Anzeneder, T.; Veeck, J.; Hartmann, A.; Knuchel, R.; Dahl, E. Promoter hypermethylation of the tumor-suppressor genes ITIH5, DKK3, and RASSF1A as novel biomarkers for blood-based breast cancer screening. Breast Cancer Res. 2013, 15, R4. [CrossRef] [PubMed]

51. Brooks, J.D.; Cairns, P.; Shore, R.E.; Klein, C.B.; Wirgin, I.; Afanasyeva, Y.; Zeleniuch-Jacquotte, A. DNA methylation in pre-diagnostic serum samples of breast cancer cases: Results of a nested case-control study. Cancer Epidemiol. 2010, 34, 717-723. [CrossRef] [PubMed]

52. Wu, H.C.; Delgado-Cruzata, L.; Flom, J.D.; Perrin, M.; Liao, Y.; Ferris, J.S.; Santella, R.M.; Terry, M.B. Repetitive element DNA methylation levels in white blood cell DNA from sisters discordant for breast cancer from the New York site of the Breast Cancer Family Registry. Carcinogenesis 2012, 33, 1946-1952. [CrossRef] [PubMed]

53. Xu, X.; Gammon, M.D.; Hernandez-Vargas, H.; Herceg, Z.; Wetmur, J.G.; Teitelbaum, S.L.; Bradshaw, P.T.; Neugut, A.I.; Santella, R.M.; Chen, J. DNA methylation in peripheral blood measured by LUMA is associated with breast cancer in a population-based study. FASEB J. 2012, 26, 2657-2666. [CrossRef] [PubMed]

54. Chan, K.C.; Zhang, J.; Hui, A.B.; Wong, N.; Lau, T.K.; Leung, T.N.; Lo, K.W.; Huang, D.W.; Lo, Y.M. Size distributions of maternal and fetal DNA in maternal plasma. Clin. Chem. 2004, 50, 88-92. [CrossRef] [PubMed]

55. Radpour, R.; Sikora, M.; Grussenmeyer, T.; Kohler, C.; Barekati, Z.; Holzgreve, W.; Lefkovits, I.; Zhong, X.Y. Simultaneous isolation of DNA, RNA, and proteins for genetic, epigenetic, transcriptomic, and proteomic analysis. J. Proteome Res. 2009, 8, 5264-5274. [CrossRef] [PubMed]

56. Li, Y.; Zimmermann, B.; Rusterholz, C.; Kang, A.; Holzgreve, W.; Hahn, S. Size separation of circulatory DNA in maternal plasma permits ready detection of fetal DNA polymorphisms. Clin. Chem. 2004, 50, 1002-1011. [CrossRef] [PubMed]

57. Van der Vaart, M.; Pretorius, P.J. The origin of circulating free DNA. Clin. Chem. 2007, 53, 2215. [CrossRef] [PubMed]

58. Radpour, R.; Barekati, Z.; Kohler, C.; Lv, Q.; Burki, N.; Diesch, C.; Bitzer, J.; Zheng, H.; Schmid, S.; Zhong, X.Y. Hypermethylation of tumor suppressor genes involved in critical regulatory pathways for developing a blood-based test in breast cancer. PLoS ONE 2011, 6, e16080. [CrossRef] [PubMed]

59. Ehrich, M.; Nelson, M.R.; Stanssens, P.; Zabeau, M.; Liloglou, T.; Xinarianos, G.; Cantor, C.R.; Field, J.K.; van den Boom, D. Quantitative high-throughput analysis of DNA methylation patterns by base-specific cleavage and mass spectrometry. Proc. Natl. Acad. Sci. USA 2005, 102, 15785-15790. [CrossRef] [PubMed]

60. Edge, S.B.; Compton, C.C. The American Joint Committee on Cancer: The 7th edition of the AJCC cancer staging manual and the future of TNM. Ann. Surg. Oncol. 2010, 17, 1471-1474. [CrossRef] [PubMed]

61. Tang, Q.; Holland-Letz, T.; Slynko, A.; Cuk, K.; Marme, F.; Schott, S.; Heil, J.; Qu, B.; Golatta, M.; Bewerunge-Hudler, M.; et al. DNA methylation array analysis identifies breast cancer associated RPTOR, MGRN1 and RAPSN hypomethylation in peripheral blood DNA. Oncotarget 2016, 7, 64191-64202. [CrossRef] [PubMed]

(C) 2018 by the authors. Licensee MDPI, Basel, Switzerland. This article is an open access article distributed under the terms and conditions of the Creative Commons Attribution (CC BY) license (http:/ / creativecommons.org/licenses/by/4.0/). 